\title{
INDEXICALS AND NAMES IN PROVERBS
}

\begin{abstract}
This paper offers an analysis of indexical expressions and proper names as they are used in proverbs. Both indexicals and proper names contribute properties rather than objects to the propositions expressed when they are used in sentences interpreted as proverbs. According to the proposal, their contribution is accounted for by the mechanism of descriptive anaphora. Indexicals with rich linguistic meaning, such as 'I', 'you' or 'today', turn out to be cases of the attributive uses of indexicals, i.e. uses whose contribution relies on the linguistic meaning of the word. Third person pronouns, names of locations as well as surnames are analyzed as non-attributive descriptive uses.

Keywords: indexicals, proverbs, descriptive indexicals, attributive uses of indexicals.
\end{abstract}

\section{Introduction}

In "Demonstratives" David Kaplan proposed an analysis of indexicals, according to which an indexical such as "today" refers to the day of utterance on each of its deictic uses. But in a footnote to the same paper (1989, page 510), when he discusses the possibility of the existence of character shifting operators - which he calls monsters - and claims that English does not contain such operators, Kaplan mentions a possible exception to his own thesis. The exception is the following proverb:

$\left(^{*}\right) \quad$ Never put off until tomorrow what you can do today.

Kaplan asks rhetorically "What can one say about this?".1

Instead of addressing the question of the existence of monsters directly, I will try to answer the rhetorical question of Kaplan. I will propose an interpretation of indexicals in proverbs according to which uses of indexicals in proverbs are a special case of the descriptive use of indexicals.

My paper will thus consist of two parts: in the first part (Sections 2) I will introduce my analysis of descriptive indexicals and in the second 
(Sections 3 and 4) I will use the mechanisms just introduced for the analysis of proverbs such as $\left(^{*}\right)$ as well as for proverbs containing proper names.

\section{Descriptive Uses of Indexicals}

There are many types of uses of pronouns and Kaplan was concerned only with what linguists call the deictic uses. But for the pronoun 'he', for example, we can mention at least 5 types of uses: ${ }^{2}$

(1) $\mathrm{He}_{1}$ [pointing at John Paul II] is speaking bad Italian. deictic

(2) If John Paul II does not practice his Italian, he $e_{2}$ will anaphoric always have a Polish accent.

(3) If somebody does not practice his Italian, he $\mathrm{h}_{3}$ will bound always have an accent.

(4) $\mathrm{He}_{4}$ [pointing at a picture of John Paul II] is my hero. deferred

(5) $\mathrm{He}_{5}$ is usually an Italian, but this time they thought descriptive it wise to elect a Pole.

[uttered by someone gesturing towards JP II as he delivers a speech with a Polish accent shortly after his election]

Descriptive uses of indexicals are uses where indexical utterances express general propositions (see Nunberg 1993, 2004; Recanati 1993, 2005; Elbourne 2005, 2008; Hunter 2010, Stokke 2010, Galery 2008, Kijania-Placek 2012, 2012a, 2014, 2015, 2015a, 2016). In example (5) one expresses not a singular proposition about John Paul II, but a general one, concerning all popes. Because 'usually' is a quantifier that requires a range of values to quantify over, and because 'he' in its standard interpretation provides just one object, there is a tension in this sentence which triggers the search for an alternative interpretation. The tension is not caused by the fact that John Paul II himself is the possible referent but it is a tension between the generality of the quantifier and the singularity of the indexical in its default interpretation. The tension would be there regardless of who the referent was. Intuitively we know that with the use of the pronoun 'he' we point at John Paul II and by doing so we make his property of being the pope more salient. We know that it is this property that plays a role in the truth conditions of the proposition expressed, which is 'Most popes are Italian'. 


\subsection{The Mechanism of Descriptive Anaphora}

I propose treating descriptive uses of indexicals as a special kind of anaphoric use which I call descriptive. ${ }^{3}$ In the mechanism of descriptive anaphora, the antecedent of the anaphora stems from the extra-linguistic context: it is an object identified through the linguistic meanings of the pronoun (in the case of pure indexicals) or by demonstration (for demonstratives). In a communication context, those objects serve as a means of expressing content and, as such, they acquire semantic properties. The antecedent is used as a pointer to a property corresponding to it in a contextually salient manner and that property contributes to the general proposition expressed. The structure of the general proposition is determined by the binary quantifier that triggered the mechanism of descriptive anaphora in the first place. The anaphora is descriptive in the sense that the antecedent does not give a referent for the pronoun. It gives a property which is not a referent - the property retrieved from the context serves as a context set that limits the domain of the quantification of the quantifier.

The descriptive use of an indexical is not its basic use. The descriptive interpretation process is triggered by the semantic inadequacy of its basic uses: deictic, (classically) anaphoric, or deferred. Typically, descriptive anaphora is triggered at the level of linguistic meaning by the use of quantifying words such as 'traditionally', 'always', or 'usually', whose linguistic meanings clash with the singularity of the default referential reading of indexicals (and those quantifiers need not be overt). As a result, the pronoun's basic referential function is suppressed.

Coming back to example (5),

He is usually an Italian.

The linguistic meaning of 'he' requires reference to one particular person but 'usually' is a quantifier that here quantifies over a set of people. This tension triggers a search for an alternative interpretation via descriptive anaphora, with John Paul II as the demonstrated antecedent. I repeat that John Paul II is not the semantic value for 'he' as no antecedent is ever a value for the anaphora - it gives the value. The salient property of John Paul II - 'being a pope' - is the semantic value of 'he'. 'usually' is a binary quantifier - $\operatorname{USUALLY}_{x}(\varphi(x), \psi(x))$ - analysed according to the generalized quantifiers theory (e.g. Barwise and Cooper 1981).4 The structure of the proposition is thus as follows:

$$
\operatorname{USUALly}_{x}(\operatorname{POPE}(x), \operatorname{ItALian}(x)),
$$


and USUALLY has the truth conditions of the majority quantifier: ${ }^{5}$

$$
M^{g i} \models \operatorname{USUALLY}_{x}(\varphi(x), \psi(x)) \text { iff }\left|\varphi^{M g i} \cap \psi^{M g i}\right|>\left|\varphi^{M g i} \backslash \psi^{M g i}\right| .
$$

Such an analysis gives the intuitive reading for (5).

In general, the structure of the interpretation can be given by the following schema:

$$
\mathrm{IND} \text { is } \mathrm{Q} \psi \quad \Rightarrow \quad \mathrm{Q} x(\varphi(x), \psi(x))
$$

where IND is an indexical, Q is a quantifier, $\varphi$ is the property corresponding to the object which is the antecedent of IND and $\Rightarrow$ should be read as 'expresses the proposition'. I take it that adverbs of quantification, such as 'always' or 'usually', quantify over events or objects.

\subsection{Other Types of Descriptive Indexicals}

I distinguish two other types of descriptive uses of indexicals (compare Kijania-Placek 2012, 2015 and 2015a). They differ only in what causes the search for an alternative interpretation, but the mechanism of the interpretation is the same. In type II, the descriptive interpretation is considered as a result of the unavailability of a referent in the context. Some propositional attitude ascriptions can be analysed in this way (compare Kijania-Placek 2015). I will not talk about these cases, however, as they will not be important in the analysis of proverbs.

In type III, the descriptive interpretation is considered because of the irrelevance of the referential interpretation. Usually there would be a conflict with the pragmatic purpose of the utterance such as a warning, or scolding. I will show what I mean with the help of an example of Emma Borg:

'You shouldn't have done that, she might have been a dangerous criminal' said to the child who has just let her sweet, grey-haired grandmother in, but without checking first to see who it was (Borg 2002).

Assuming the referential interpretation of 'she', this sentence is semantically consistent and attributes a modal property to the grandmother. Such a proposition is true if and only if the grandmother is a dangerous criminal in a counterfactual situation. Such a trivial proposition is, however, impotent as a rebuke: in a metaphysical sense, everybody could be a dangerous criminal. Somebody would have to be a criminal in the actual situation to be a threat to the child and we assumed that the grandmother is not dangerous in this sense. The sense of the scolding is thus not a singular proposition 
about the grandmother and so the propositional contribution of 'she' is not the grandmother herself.

But perhaps the mistake was to interpret the possibility metaphysically. Maybe we should interpret it epistemically: "For what you knew, it has not been excluded that..."? Indeed, Recanati (1993) claims that the epistemic interpretation of modals in such contexts saves the referential interpretation of indexicals. I think he is wrong in this respect: it is simply not true that the child did not know about her grandmother that she was not a dangerous criminal. On the contrary, by the assumption that constitutes this example, the child knew that her grandmother was not a dangerous criminal. But the idea of an epistemic interpretation of the modal is, I think, correct, because the concept of scolding assumes the relevance of the actual situation, not counterfactual ones. So the epistemic interpretation of modality, together with the mechanism of descriptive anaphora give the relevant interpretation of (6):

She might have been a dangerous criminal.

We search the context for a salient property of the grandmother, who is the demonstrated antecedent of 'she'. In this case it is 'being the person who rung the bell'. The quantifier which gives the structure of the general proposition embedded under the modal operator is here the covered definite description quantifier. As a result we obtain the proposition:

$$
\operatorname{Might-HAVE}_{\text {epist }}\left(\operatorname{THE}_{x}\left(\operatorname{RinGS-THE}-\operatorname{BeLl}_{(}(x), \operatorname{CRIMINAL}(x)\right)\right),
$$

where the truth conditions for the definite description quantifier are the expected ones,

$$
M^{g i} \models \operatorname{THE}_{x}(\varphi(x), \psi(x)) \text { iff }\left|\varphi^{M g i}\right|=1 \text { and } \varphi^{M g i} \subseteq \psi^{M g i} \text {, }
$$

and MIGHT-HAVE epist $_{\text {is }}$ the epistemic modality relativized to the relevant in this context information base, i.e. the knowledge of the child at the moment of opening the door. We thus get: 'Your knowledge at the moment of opening the door did not exclude it that the person who rung the bell was a dangerous criminal', which is the intended interpretation (compare Kijania-Placek 2015a).

But the irrelevance of referential interpretations, which triggers the mechanism of descriptive anaphora, is not always connected with modal contexts. Let us consider another example of Nunberg. A doctor during a lecture points to his own chest and utters: 
(7) When a person is shot here, we can usually conclude that it was not suicide. (Nunberg 1993)

Here 'usually' does not quantify over persons being shot but over events of shooting a particular place. Because it is not excluded that somebody might be shot several times during one event, there is no semantic inconsistency between the referential reading of 'here' and the quantifier 'usually'. It is thus not a case of a descriptive use of an indexical of type I. But, anyhow, we are not concerned with the particular place demonstrated, because it is obvious for the addressee that the speaker is demonstrating a chest which has not been shot at in the relevant way pertaining to murder. The referential interpretation would thus give a blatantly false and thus irrelevant proposition. That is why while interpreting (7) we deploy the mechanism of descriptive anaphora and treat the demonstrated place as an antecedent for 'here'. The antecedent gives us the semantic value for 'here' and the semantic value is the salient property of 'being a place in the middle of the chest'.

This example is especially interesting, because its structure is based on an implication in the scope of an adverb of quantification 'usually':

$$
\operatorname{USUALLY}(\alpha \rightarrow \beta) \text {. }
$$

Such a structure is postulated for all adverbs of quantification (Quine 1941, Lewis 1975) but it is seldom explicit. As a result, the indexical 'here' in this example does not provide the first argument of the quantifier in full, but just completes it. The resulting proposition is the following:

$$
\operatorname{USUALLY}_{x}(\operatorname{SHOT-IN-CHEST}(x), \operatorname{CAN-ASSUME}(\neg \operatorname{SUICIDE}(x)))
$$

- "Usually we can conclude that a shot in the chest was not a suicide".

\section{Proverbs}

Proverbs by their very nature express general rules or truths and do not concern just particular cases. ${ }^{6}$ I think that it is exactly the context of a proverb that triggers the non-referential, general reading of the indexical. After all, if somebody does not recognize a saying as a proverb, he can see it as concerning himself directly and interpret the indexical referentially. But such a reading trivialises the proverb. It is thus the irrelevance of the 
referential interpretation that triggers the descriptive interpretation, which makes indexicals used in proverbs cases of descriptive uses of indexicals of type III.

\subsection{Attributive Uses of Indexicals}

In typical cases of descriptive readings, like example (5), indexicals do not contribute their linguistic meaning to the proposition expressed but rather some other property which is salient in the context. However, I will try to show that the context of a proverb is a special context that triggers the interpretation of some indexicals - and proper names, see Section 4 - via the property which is part of their indexical meaning. Thus I call such special kinds of the descriptive uses of indexicals attributive uses, in analogy to Donnellan's (1966) attributive uses of definite description, whose propositional contribution is their linguistic meaning.

Particularly interesting here are the uses of first and second person pronouns or words such as 'today' or 'yesterday', which have rich linguistic meaning. I will introduce my analysis with the help of the initial example:

Never put off until tomorrow what you can do today.

If we recognize the sentence as a proverb, we are additionally aware that the interpretation should not rely on particular features of the context of use, which would be what we do in typical cases of descriptive interpretation. Yet if we abstract from individual occasions of use, what is left is the property that is common to all addressees of the sentence, i.e. the property of 'being the addressee', which is part of the linguistic meaning of 'you'. This property contributes to the proposition expressed, making this descriptive use of the indexical attributive. ${ }^{7}$

There are three indexicals in this sentence, 'you', 'today', and 'tomorrow'. Their linguistic meaning is, respectively: 'the addressee', 'the day of utterance', and 'the day following the day of utterance'. I will ignore the metaphorical air of 'today' and 'tomorrow' here and concentrate first on this use of 'you'. According to the descriptive anaphora interpretation, the antecedent of this indexical is the object given in the context by the linguistic meaning of the indexical. But the context of a proverb makes us abstract from particular properties of the individual and concentrate on his general property of being the addressee in this case. As everybody is the addressee of a proverb, this property boils down to something like 'being human'. In the same way, 'today' brings the property of 'being a present day' and 'tomorrow' - of 'being a future day'. 
In the case of $(*)$, 'you' and 'today' limit the domain of quantification of the quantifier 'never' - we are talking here about activities which should be done at a particular time - while 'tomorrow' contributes to the second argument of the quantifier. The quantifier can be overt, like in this case, or covered, like in

Do not put off until tomorrow what you can do today.

In $\left(^{*}\right)$, the quantifier 'never' quantifies over events. According to Davidson's semantics (Davidson 1980), there is a place for an agent and time in the structure of every event (the place of the event and other aspects will not be considered here). The structure of the expressed general proposition will thus, ignoring the imperative mode of the utterance, be:

$$
\begin{aligned}
& \operatorname{EVERY}_{x}(\operatorname{AGENT-IS-HUMAN}(x) \wedge \text { CAN }(\text { DO-IN-DAY-OF-UTTERANCE }(x)), \\
& \neg \text { PUT-OFF-UNTIL-NEXT-DAY }(x)) .
\end{aligned}
$$

'Never' is a negative counterpart of a general quantifier, but the force of the negation concerns the 'put off' verb and is thus relegated to the second argument of the universal quantifier. The universal quantifier has the following natural truth conditions:

$$
M^{g i} \models \operatorname{EVERY}_{x}(\varphi(x), \psi(x)) \text { iff } \varphi^{M g i} \subseteq \psi^{M g i}
$$

By limiting the range of quantification to objects that might be subjects to obligations, we make the limitation to people redundant and the proposition - with 'should' added by the imperative mode not explicitly analysed here - is thus: 'Nothing, which could be done in a particular day should be postponed until next day'. The metaphorical aspect of 'the following day' (as well as of 'the a particular day'), which stretches the sense of the phrase to 'in the future' I leave here unanalysed.

We might ask why are not all descriptive uses attributive, at least the uses of pure indexicals, if the property that is part of their linguistic meaning is always available? The answer is that its constant presence works exactly against its salience, which is necessary for the mechanism of descriptive anaphora to work. We must abstract from the particular context of use, as we do in proverbs, to make the property included in the linguistic meaning visible. 


\subsection{Non-Attributive Descriptive Uses of Indexicals in Proverbs}

The rich linguistic meaning of indexicals such as 'you', 'today', or 'tomorrow' makes them especially useful for expressing very general content. Other examples can be found in The Oxford Dictionary of English Proverbs, such as:

Tomorrow never comes.

One hour today is worth two tomorrow.

You are what you eat.

The more you get, the more you want.

If you play with fire you get burnt.

Practise what you preach.

You cannot lose what you never had.

Be careful what you pray for, you might get it.

As you make your bed, so you must lie upon it.

Demonstratives such as 'he' or 'she', whose linguistic meaning is sparse and of rather a negative character - 'he' means something like 'a male salient in the context, who is neither the addressee nor the speaker' - are usually not used for expression of a completely general content but are used in proverbs whose application is limited to particulate types of situations. Let me give another example of Nunberg's:

$[\mathrm{W}] \mathrm{e}$ are at a party and see Ralph in friendly conversation with Clovis, apparently unaware that Clovis has been carrying on a clandestine affair with his wife. I point at Ralph and say:

It's like they say: he is always the last one to know

(Nunberg 1993)

The phrase 'like they say' cancels any doubts as to the nature of the utterance - it is a proverb of some kind and the sense of the proverb is general. It is thus this phrase that triggers the descriptive interpretation. Here it will not be an attributive interpretation because the linguistic meaning of 'he' does not specify any particular role in communication but a descriptive one which is based on a particular property of an individual, salient in the context. The relevant property we are looking for here is a property of the demonstrated object - Ralph, whose salient property is that of 'being a husband'. The context of a proverb gives the generality of the proposition 
- we are concerned not just with this particular husband but with any husband and the structure is given this time by a covered universal quantifier $\operatorname{EVERY}_{x}(\operatorname{Husband}(x), \psi(x))$. This quantifier quantifies over people.

But there is another quantifier in this sentence - 'always' - and it quantifies over events. The property that limits the domain of quantification of this quantifier is given by a covered argument of the verb 'know'. It is a verb expressing a relation between somebody who knows and the something he knows. The relevant property is 'an affair of one's wife' and thus we get the following proposition:

$$
\begin{aligned}
& \operatorname{EVERY}_{x}\left(\operatorname{Husband}(x), \operatorname{ALWAYS}_{y}(\operatorname{AFFAIR-OF-WIFE-OF}(y, x) \text {, }\right. \\
& \text { LAST-ONE-TO-KNOW-OF }(x, y)) \text { ) }
\end{aligned}
$$

- '(Every) husband is always the last one to know (about his wife's affair)'. The truth conditions of the quantifier 'always' are those of a universal quantifier:

$$
M^{g i} \models \operatorname{ALWAYS}_{x}(\varphi(x), \psi(x)) \text { iff } \varphi^{M g i} \subseteq \psi^{M g i} .
$$

Perhaps it is instructive to explain why the analysed examples are not classified as descriptive uses of type I. After all, there are quantifiers such as 'never' and 'always' present, which makes them superficially similar to

He is usually an Italian.

The reason why I do not classify them in the same way is that in (5) it is not just the co-occurrence of 'usually' and 'he' that triggers the descriptive interpretation, but the fact that in this usage the quantifier quantifies over those same type of objects - people - that the pronoun refers to. In (9) the overt quantifier quantifies over events and such a quantification is in principle not incompatible with one person being an agent of all those events. So it is only the irrelevance of the referential interpretation, not its semantic inconsistency, which triggers the descriptive interpretation and that is why (9) is a case of descriptive indexicals of type III. The same is true for (7).

\section{Proper Names in Proverbs}

Proper names are usually used to refer to particular persons or things, with the exclusion of others. However, in proverbs their semantic contribution is not referential as they enable predication about anybody who meets 
a certain condition. Since proper names in proverbs seem to behave like indexicals, i.e. their referential function is suppressed and their contribution is general, in this section I will try to apply the interpretational strategies proposed for indexicals in Section 3 to proper names.

My initial empirical observation is that there are not that many examples of proper names in proverbs. ${ }^{8}$ At the end of this section I will venture an explanation of this fact. Additionally, the proper names being used are either first names on the one hand or surnames and location names on the other. I believe that these two groups have different types of contribution to the truth condition of an utterance and in what follows I will propose an analysis that relies on the mechanism of descriptive anaphora but treats only the first group as attributive.

\subsection{First Names in Proverbs}

I will concentrate on the analysis of the following examples:

(10) All work and no play makes Jack a dull boy, ${ }^{9}$

(11) Czego Jaś się nie nauczy, tego Jan nie będzie umiał.

[Polish, gloss: What little Johnny will not learn, John will not know.]

The intended meaning of (10) is not limited to specific Jack and that of (11) to specific Jan. Rather, the contribution of 'Jack' in (10) is the general condition of being a man.

\subsubsection{Predicative Analysis of Proper Names in Proverbs}

According to referentialist theories of the semantics of proper names (Mill 1843, Kripke 1972/1980, Perry 2012, Kaplan 1989, Jeshion 2015, Recanati 1993, Soames 2002, Salmon 1986), the semantic contribution of a name is an individual object (or person). Descriptive theories of proper names (Frege 1892, Russell 1911, Strawson 1959, Searle 1958, Jackson 1998, Chalmers 2004, Poller 2014) postulate descriptive condition as a semantic value, but since this condition must be an identifying condition, the resulting meaning concerns just an individual bearer of a proper name as well. Predicativism about proper names (Burge 1973, Matuschansky 2008, Fara 2015) on the other hand, is a theory according to which proper names are not singular terms but predicates and thus these theories seem to provide the appropriate - not singular - kind of condition. Yet, predicativists 
propose a very specific condition for a name like 'Jack', the so-called Being Called Condition. Fara claims that proper names are "multiply applicable predicates that are true of just those things that are bearers of the name" (2015a, p. 251), where by a bearer she means any individual who happens to be called by that name.

BCC, Being Called Condition

(BCC) ' $N$ ' (when a predicate) is true of a thing just in case it is called $N .{ }^{10}$ Since according to Fara "names are predicates in all of their occurrences" (Fara 2015, p. 60), for the name 'Jack', as it appears in (10), we would have: (BCC-Jack) 'Jack' is true of a thing just in case it is called Jack, and the semantic value of this name would be

$$
[[\text { Jack }]]=\{x: x \text { is called Jack }\}
$$

But it is no part of the semantic contribution of 'Jack' in (10) that a person is called Jack. Thus, while predicativism gives the right form of a semantic value - a multiply applicable condition - it does not give an adequate content of that condition.

\subsubsection{Attributive Analysis of First Names in Proverbs}

The general, multiply applicable condition contributed by a name in a proverb can be accounted for with the help of the same mechanism of descriptive anaphora which I have proposed for the analysis of indexicals in proverbs in Section 3. On this analysis, a name used descriptively, as in (10), would be (descriptively) anaphoric on a particular Jack, available in the context of an utterance, which Jack would contribute his salient feature to the proposition expressed..$^{11}$ But since the context of a proverb invites abstraction from individual contexts of use, no specific features, particular just to Jack, will be relevant here. Yet, if we abstract away from all of the particular features, we are left with the condition stemming from the fact that 'Jack' is prototypically a name of a person, of a man; 'a man' in its general meaning comprising females as well. This general feature may be constrained by the linguistic context of the utterance, as I will exemplify in the next paragraph. Thus the (descriptively) anaphoric use of 'Jack' in (10) - with the universal quantifier supplied by the context of a proverb - gives the following proposition (I leave the interpretation of 'boy' as a person in this proverb unjustified):

$$
\operatorname{EVERY}_{x}(\text { MAN-WHO-ONLY-WORKS- }(x), \operatorname{DULL-PERSON}(x)) .
$$


In this case, as it was in the case of attributive uses of indexicals, the antecedent itself seems to be dispensable, as the resulting feature is not his or her feature but a general linguistic feature of the expression. This makes the attributive use of an indexicals and of proper names a limiting case of a descriptive use and the term 'attributive use' derives from the fact that the resulting semantic contribution consists of features linguistically connected with the expression in question.

The interpretation of 'Jack' is a bit different in

Every Jack has his Jill. ${ }^{12}$

due to the interplay between 'Jack' and 'Jill'. In analogy to the meaning of 'a man' that can mean both a person in general or a male person, while 'a woman' always means only a female person, a semantic contribution of a feminine name, such as Jill, in proverbs always includes the feature of being a female. This feature interacts in (12) with the contribution of 'Jack', limiting its extension to male, i.e. non-female, persons. The (descriptively) anaphoric interpretation of (12) will thus be:

$$
\operatorname{EVeri}_{x}\left(\operatorname{Male}-\operatorname{Person}(x), \operatorname{EXists}_{y}(\operatorname{Female} \operatorname{Person}(y), R(y, x))\right),
$$

where $R$ is the relation of being the right (appropriate, destined) romantic partner for somebody. In (11) the semantic contribution of 'Jan' (John) interferes with that of 'Jaś' (little Johnny), introducing the properties of 'young' and 'old/adult' into the semantic contributions of the respective names. As a result the mechanism of descriptive anaphora generates the following proposition:

$$
\begin{aligned}
& \operatorname{EVERY}_{x}\left(\operatorname{Man}(x),\left(\operatorname{EVERY}_{y}(\operatorname{LEARNABle}(y) \wedge \neg \text { LEARN-While-Young }(x, y),\right.\right. \\
& \neg \text { KNOW } / \operatorname{BE} \operatorname{ABLE} \text { TO LEARN-WHiLe-AdUlt }(x, y)))
\end{aligned}
$$

- 'What someone does not learn while young, will not know (be able to learn) as an adult'.

The same mechanism of interference between the semantic contribution of words can be deployed to account for the historical change in meaning - or at least in application conditions - of (10). Formerly, ${ }^{13}$ the connotation of the noun 'work' was stereotypically limited to menial work, which accounts for the fact that 'Jack' was "variously used as a familiar name for a sailor, a member of the common people, a serving man, and one who does odd jobs" OCDP. ${ }^{14}$ Today's usage does not necessarily retain this connotation of 'work', arguably due to the fact that almost everybody works 
nowadays. Accordingly, The Oxford Dictionary of Proverbs (2015 edition) elucidates the proverb as a "warning that devoting one's life entirely to work, without time off to relaxation and amusement, makes a person very boring." (ODP, p. 352 [my emphasis, KK-P]). Thus the changed meaning of the words in the linguistic context of a proper name influences the changed meaning of the entire proverb by interfering with the interpretation of first names that are part of it.

\subsection{Surnames and Location Names in Proverbs}

Predicativist theories will be of no help in the interpretation of location names in proverbs either, as it seems that 'being called Rome' is no part of the propositional contribution of 'Rome' to the general proposition expressed in proverbs such as:

(13) When in Rome, do as the Romans do.

or

All roads lead to Rome.

But this use is not an attributive use either, because the relevant feature is not just that of being any location but a much limited feature, stemming from particular features of the famous Rome itself. The context of a proverb requires concentration on relatively general features of the town but yet specific enough to distinguish it from just any town. So while 'Jack' could in principle be exchanged for any other male name without a change of meaning, ${ }^{15}$ exchanging 'Rome' with 'Pcim', a small town in Poland, will leave the utterance either unintelligible or comprehended only with the help of an echoic reference to the original proverb and thus inheriting its meaning. ${ }^{16}$

Interpreted according to the mechanism of descriptive anaphora, the occurrence of 'Rome' in (13) is treated as anaphoric on the town itself and its semantic contribution is a paradigmatic feature of the town, such as 'being an important town'. The immediate linguistic context of the name, i.e. other words comprising the sentence, contribute to the salience of a particular feature. Thus in (13) the property might be 'being a place (town or country) big and important enough to establish its own social customs and standards', for (14) - 'being a place of great geographical and political importance', while for (15):

Rome was not built in a day. 
and its Polish counterpart:

Nie od razu Kraków zbudowano.

[Krakow was not built at once]

it could even be the condition of 'being a major enterprise'. With universal quantifiers supplied by the context of a proverb, an analogical analysis of 'Romans', and attributive analysis of 'you' (see Section 3 above), the mechanism of descriptive anaphora yields the following proposition as the interpretation of (13):

$$
\begin{aligned}
& \operatorname{EVERY}_{x}\left(\operatorname{Man}(x), \operatorname{EVERy}_{y}(\operatorname{COUNTRy}(y) \wedge \operatorname{visits}(x, y),\right. \\
& \text { SHOULD-BEHAVE-LIKE-THE-PEOPLE-IN }(x, y))) \text {. }
\end{aligned}
$$

Surnames used in proverbs are semantically on a par not with first names but with location names. The meaning of a proverb is derived from the particular features of the famous bearer of a surname - be it real bearer or a fictional character - and not only replacing the surname with a different one, but connecting it with a different bearer of the same surname (or a surname of the same form, depending on the criteria of identity for names one favours), would change the meaning of a proverb or render it meaningless. ${ }^{17}$ In the Polish proverb:

(17) Na słowie harcerza polegaj jak na Zawiszy.

[Rely on scout's name the way you can rely on Zawisza]

the paradigmatically characteristic feature of Zawisza Czarny, a Polish medieval knight famous for his courage, prudence and reliability, is relied upon and the resulting proposition is: ${ }^{18}$

$$
\begin{aligned}
& \operatorname{EVERY}_{x}\left(\operatorname{SCOUT}(x), \operatorname{EVERY}_{y} \operatorname{EVERY}_{z}(\operatorname{Man}(y) \wedge \operatorname{UTtERED-By}(z, x),\right. \\
& \text { CAN-RELY-TO-A-GREAT-EXTENT-ON }(y, z))
\end{aligned}
$$

- 'Everybody can rely to a great extent on the word of a scout'.

The analysis proposed above allows for an explanation of the relatively infrequent use of proper names in proverbs. The probable reason is that the contribution of a first name in a proverb is often very similar, if not identical to that of an indexical. With an indexical's much clearer and uncontroversial linguistic meaning at hand, it is not surprising that their use for the same aim will be more frequent. Surnames and location names, on the other 
hand, are extremely contextual, which explains why only a few names, such as Rome, survived the passage of time and reappear in new editions of dictionaries of proverbs.

\section{Conclusion}

Based on my interpretation of descriptive indexicals via a mechanism of descriptive anaphora, I have proposed an analysis of indexicals and proper names used in proverbs as a special case of descriptive use. Depending on how rich their linguistic meaning is, the indexicals used in proverbs either form a subclass of descriptive uses which are attributive - their propositional contribution is their linguistic meaning - or contribute a property retrieved from the immediate context of utterance to the proposition expressed. This explains why indexicals of rich linguistic meaning, such as 'I', 'you', 'today', or 'tomorrow' are often used in proverbs with a very general meaning, while third person pronouns, whose linguistic meaning does not constrain a very specific role in communication for the referent, are used in proverbs whose meaning is just pertinent to particular types of situation. Within the class of proper names, first names occurring in proverbs are analysable as attributive uses while surnames and location names, due to their highly contextual character, as non-attributive descriptive uses.

\section{Acknowledgments}

This work has been partly supported by the (Polish) National Science Centre 2013/09/B/HS1/02013 grant.

\section{N O T E S}

${ }^{1}$ He attributes this counterexample to Richmond Thomasson (Kaplan 1989, p. 510).

${ }^{2}$ Example (5) is taken from Recanati (1993) and is a version of an example by Nunberg (1992).

3 Compare Kijania-Placek 2012, 2012a, 2014, 2015, 2015a and 2016.

${ }^{4}$ I use SMALLCAPS font style for formal counterparts of natural language quantifiers and predicates.

${ }^{5}$ In what follows $M$ is a model, $g$ is an assignment of objects from the domain of the model to individual variables, $i$ is a context, $\models$ is a satisfaction relation obtaining between a sentence (or an open formula) and a model and context, under an assignment; $\varphi$ and $\psi$ are open formulas, $|A|$ signifies the cardinality of the set $A$, and $\varphi^{M g i}$ is the interpretation of formula $\varphi$ in model $M$ and context $i$ under assignment $g$.

${ }^{6}$ Here I disagree with Predelli (1996), whose analysis gives multiple but still singular readings for examples such as $\left(^{*}\right)$. Compare Everrett (2002). By general rules I do not 
just mean universally quantified rules and the specific character of the generality depends on the quantifier used in the sentence. I thus disagree with Predelli (2001) as well, as he assumes there that what he calls non-specific uses of indexicals contain an "implicit generic operator", on a par with generic uses of indefinites. Compare Heim (1982).

7 For a more extensive discussion see Kijania-Placek (2012).

8 In contrast to the case of indexicals, which are limited in kind, it is not possible to make an automated search for names in proverbs. My observation is thus based on a item by item search of the database "1000 ENGLISH PROVERBS", accessed from https://suratiundhiyu.files.wordpress.com/2011/02/1000-english-proverbs.pdf

9 From The Concise Dictionary of Proverbs [CDP, for short].

10 Fara (2015, p. 64). The BCC condition as well as the details of each predicativist theory differ among the mentioned authors. The most important, perhaps, is the difference between 'the' predicativists (Fara, Matuschansky) and 'that' predicativists (Burge) that amounts to divergent ways of accounting for referentialist intuitions about "names appearing as bare singulars in argument position". The differences will not, however, be important for our purposes and thus in what follows I will treat all predicativist theories as one theory.

${ }^{11}$ In the case of proper names - and in contrast to indexicals - the referent of a name does not have to be present in the immediate context of the utterance. Rather, the context provides the relevant social convention linking the particular use of a name with a specific person.

12 Similar examples include: 'A good Jack makes a good Jill' ( The Oxford Dictionary of English Proverbs, ODP for short).

13 Its use was recorded as far back as in Howell 1659; see ODP.

14 This note, although formulated as a general thesis, has in fact been made with reference to the use of 'Jack' in a different proverb: 'Jack is as good as his master'. In this case the interplay of 'master' and 'Jack' can account for retaining of the original limited connotation of the name.

15 We might envisage a language that does not already contain a proverb closely equivalent to 'Every Jack has his Jill'. Prefixing a translation of this proverb into that language, with names changed for those which are appropriately typical, with "To coin a new proverb..." ("To coin a new proverb, every Steffen has his Maria" [in that other language]), would probably be understood in the same way as 'Every Jack has his Jill' is in English.

16 On echoic utterances see Sperber \& Wilson (1986) and Wilson \& Sperber (1992).

17 In "Przysłowia polskie odnoszące się do nazwisk szlacheckich i miejscowości" [Polish provers referring to noble surnames and location names] Aleksander Weryha-Darowski gathered and explain the meaning of selected Polish proverbs containing surnames and location names. Almost all of them are meaningless nowadays and do not function as proverbs due to the highly contextual character of the names that have been used.

18 The attributive analysis of 'you' proceeds according to the mechanism introduced in Section 3. I leave the synecdochic use of 'word' in this example unexplained.

\section{R E F E R E N C E S}

Barwise, J. \& Cooper, R. (1981). Generalized quantifiers and natural language. Linguistics and Philosophy 4(1), 159-219. 
Borg, E. (2002). Pointing at Jack, talking about Jill: Understanding deferred uses of demonstratives and pronouns. Mind and Language 17, 489-512.

Burge, T. (1973). Reference and Proper Names. Journal of Philosophy 70(14), 42539.

Chalmers, D. (2004). Epistemic Two-Dimensional Semantics. Philosophical Studies 118, 153-226.

Davidson, D. (1980). Essays on Actions and Events. Oxford: Oxford University Press.

Donnellan, K. (1966). Reference and definite descriptions, Philosophical Review 75, 281-304.

Elbourne, P. (2005). Situations and individuals. Cambridge, MA: MIT Press.

Elbourne, P. (2008). Demonstratives as individual concepts. Linguistics and Philosophy 31, 409-466.

Everrett, A. (2002). Predelli on procrastination. Analysis 62, 160-166.

Fara, D.G. (2015). Names are predicates. Philosophical Review 124(1), 59-117.

Fara, D.G. (2015a). 'Literal' uses of proper names. In A. Bianchi (Ed.), On Reference, Oxford: Oxford University Press, pp. 251-279.

Frege, G. (1892). Über Sinn und Bedeutung. Philosophie und Philosophische Kritik 100:25-50; transl. in Philosophical Review 57, 207-230.

Galery, T. (2008). Singular content and deferred uses of indexicals. UCL Working Papers in Linguistics 20, 157-194.

Heim, I. (1982). The Semantics of Definite and Indefinite Noun Phrases. Ph.D Thesis, published by New York: Garland Publishing, Inc., 1988.

Howell, J. (1659). Paroimiograhia. Proverbs. London.

Hunter J. (2010). Presuppositional Indexicals. Ph.D thesis, The University of Texas at Austin.

Jackson, F. (1998). From Metaphysics to Ethics: a Defence of Conceptual Analysis. Oxford: Oxford University Press.

Jeshion R. (2015). Referentialism and Predicativism About Proper Names. Erkenntnis 80, 363-404.

Kaplan, D. (1989). Demonstratives. In J. Almog, J. Perry \& H. Wettstein (Eds.), Themes from Kaplan, New York: Oxford University Press, pp. 481-563.

Kijania-Placek, K. (2012). Pochwała okazjonalności. Analiza deskryptywnych użyć wyrażeń okazjonalnych (Praise of indexicality. An analysis of descriptive uses of indexicals, in Polish). Warsaw: Semper.

Kijania-Placek K. (2012a). Deferred reference and descriptive indexicals. Mixed cases. In P. Stalmaszczyk (Ed.), Philosophical and Formal Approaches to Linguistic Analysis, Frankfurt: Ontos Verlag, pp. 241-261.

Kijania-Placek, K. (2014). Situation semantics, time and descriptive indexicals. In P. Stalmaszczyk (Ed.), Semantics and beyond. Philosophical and linguistic inquiries, Walter De Gruyter, pp. 127-148. 
Kijania-Placek, K. (2015). Descriptive indexicals, propositional attitudes and the double role of context. In H. Christiansen, I. Stojanovic, G. Papadopoulos (Eds.), Modeling and Using Context. LNAI 9405, Dordrecht: Springer, pp. 287-301.

Kijania-Placek, K. (2015a). Descriptive indexicals and epistemic modality, forthcoming in Topoi, DOI 10.1007/s11245-015-9340-5

Kijania-Placek, K. (2016). Can minimalism about truth embrace polysemy? forthcoming in Synthese, DOI 10.1007ś11229-016-1228-4

Kripke S. (1972/1980). Naming and necessity. Oxford: Blackwell.

Lewis D. (1975). Adverbs of quantification. In E. Keenan (Ed.), Formal Semantics of Natural Language, Cambridge: Cambridge University Press, pp. 3-15.

Matushansky, O. (2008). On the Linguistic Complexity of Proper Names. Linguistics and Philosophy 21(5), 573-627.

Mill J.S. (1843/1963). A System of Logic. Toronto: University of Toronto Press.

Nunberg, G. (1992). Two kinds of indexicality. In C. Barker \& D. Dowty (Eds.), Proceedings from the Second Conference on Semantics and Linguistic Theory, Columbus: The Ohio State University, pp. 283-301.

Nunberg, G. (1993). Indexicality and deixis, Linguistics and Philosophy 16, 1-43.

Nunberg, G. (2004). Descriptive indexicals and indexical descriptions. In M. Reimer \& A. Bezuidenhout (Eds.), Descriptions and Beyond, Oxford: Clarendon Press, pp. 261-279.

Perry, J. (2012). Reference and reflexivity (2nd ed.). Stanford: CSLI Publications.

Poller, O. (2014). Formal Representation of Proper Names in Accordance with a Descriptive Theory of Reference, Polish Journal of Philosophy VIII(1), $37-52$.

Predelli, S. (1996). Never put off until tomorrow what you can do today. Analysis 56, $85-91$.

Predelli, S. (2001). You Just Can't Tell. An Analysis of the Non-Specific Use of Indexicals, ms.

Quine, W.V.O. (1941). Elementary logic. New York: Ginn and Company.

Recanati, F. (1993). Direct Reference: From Language to Thought. Oxford: Blackwell.

Recanati, F. (2005). Deixis and anaphora. In Z.G. Szabo (Ed.), Semantics vs. Pragmatics, Oxford: Oxford University Press, pp. 286-316.

Russell, B. (1911). Knowledge by Acquaintance and Knowledge by Description. Proceedings of the Aristotelian Society 11, 108-128.

Salmon, N. (1986). Frege's Puzzle. Cambridge, MA: MIT Press.

Searle, J. (1958). Proper Names. Mind 67(266), 166-73.

Simpson, J.A., Speake, J. (Eds.) (2003). Concise Dictionary of Proverbs, Oxford: Oxford University Press. [abbreviated in text as CDP] 
Soames, S. (2002). Beyond Rigidity: The Unfinished Semantic Agenda of Naming and Necessity. New York: Oxford University Press.

Speake, J. (Ed.) (2015). The Oxford Dictionary of Proverbs, Oxford: Oxford University Press. [abbreviated in text as ODP]

Sperber, D., Wilson, D. (1986). Relevance: Communication and Cognition. Cambridge, MA: Harvard University Press.

Stokke, A. (2010). Indexicality and Presupposition. Explorations beyond TruthConditional Information. Ph.D thesis, University of St Andrews.

Strawson, P. (1959). Individuals: an Essay on Descriptive Metaphysics. London: Methuen.

Weryha-Darowski, A. (1874). Przysłowia polskie odnoszące się do nazwisk szlacheckich i miejscowości [Polish provers referring to noble surnames and location names; in Polish] Poznań: Księgarnia J.K. Żupański.

Wilson, D., Sperber. D. (1992). On Verbal Irony. Lingua 87(1-2), 53-76.

1000 English Proverbs, https://suratiundhiyu.files.wordpress.com/2011/02/1000english-proverbs.pdf 